\title{
Interactive effects of excess boron and salinity on histological and ultrastructural leaves of Zea mays amylacea from the Lluta Valley (Arica-Chile)
}

\author{
Elizabeth Bastías ${ }^{1}$, María B. González-Moro², and Carmen González- \\ Murua $^{2}$ \\ 'Departamento de Producción Agrícola, Centro de Agricultura y Biodiversidad del Desierto (CAyBIDE), \\ Facultad de Ciencias Agronómicas, Universidad de Tarapacá. Casilla 6-D, Arica, Chile. \\ ${ }^{2}$ Departamento de Biología Vegetal y Ecología, Facultad de Ciencia y Tecnología, Universidad del País \\ Vasco/Euskal Herriko Univertsitatea. Apdo. 644, E-48080 Bilbao, Vizcaya, Spain.
}

\begin{abstract}
E.I. Bastías, M.B. González-Moro, and C. González-Murua. 2013. Interactive effects of excess boron and salinity on histological and ultrastructural leaves of Zea mays amylacea from the Lluta Valley (Arica-Chile). Cien. Inv. Agr. 40(3): 581-595. Maize is widely cultivated throughout the world, and more maize is produced each year than any other grain. Studies on the response of maize to salinity have typically focused on physiological aspects, but few studies have addressed the effects of salinity on the anatomical and ultrastructural characteristics of different plant organs. We analyzed the cell structure and changes in tissue organization in young leaves of Zea mays L. amylacea as a consequence of high salt and boron (B) levels. Plants were treated in nutrient solutions for 20 days with concentrations of $100 \mathrm{mM}$ $\mathrm{NaCl}$ (Low salinity, L) or $430 \mathrm{mM} \mathrm{NaCl}$ (High salinity, H) in the case of saline treatments or with an excess of B supplied as boric acid to obtain $20 \mathrm{mg}(334 \mu \mathrm{M})$ or $40 \mathrm{mg}(668 \mu \mathrm{M}) \mathrm{B} \mathrm{kg}^{-1}$. The application of B under no salt and low salinity conditions did not result in ultrastructure changes in mesophyll cells (MC) or bundle sheath cells (BSC). The high salinity conditions the amylacea leaf cells showed some alterations in MC chloroplasts, which appeared swollen and rounded. The BSC chloroplasts lost their perpendicular disposition to the cell wall. Moreover, the absolute absence of plastoglobuli could indicate a greater resistance to oxidative damage.
\end{abstract}

Key words: Amylacea, amylacea maize, anatomical plant, boron, histological, salinity.

\section{Introduction}

High salt concentration in soil is one of the most important factors influencing the distribution of plants in certain natural habitats. The presence of salts is also the major constraint to food production

Received April 2, 2013. Accepted November 6, 2013. Corresponding author: ebastias@uta.cl because it limits crop yield and restricts the use of previously uncultivated land. Salt stress is a worldwide problem, especially acute in Northern and Central Asia, Australia and South America (Pessarakli and Szabolics, 1999). High salinity conditions are aggravated by the presence of $\mathrm{B}$ in soils and waters in arid and semiarid environments. High salt and B levels are found in the Lluta valley of northern Chile, where elevated 
levels of B in soils and irrigation water limit the local agricultural production to a few crops. In addition, this region has an annual precipitation less than $1 \mathrm{~mm}$ (Novoa et al., 1989). Maize is classified as a salt-sensitive crop plant, whose growth and productivity are reduced when salinity is above $2.5 \mathrm{mS} \mathrm{cm}^{-1}$, although the sensitivity depends on the cultivar (Cramer et al., 1994). Zea mays L. amylacea is a sweet maize variety welladapted to the agro-ecological characteristics of the Lluta valley; it is the main crop grown in the region. This maize variety is used as a source of germplasm to improve salt and B tolerance in other maize cultivars (Bastías et al., 2004a, b).

Salt tolerance in non-halophytic plants is a complex trait (Shi et al., 2000). Many different physiological factors may contribute to salt tolerance, such as the generation of osmoprotectants in the cytoplasm, the provision of energy by ATPases for the export of $\mathrm{Na}^{+}$and $\mathrm{Cl}^{-}$, or the presence of specific transport proteins for the movement of these ions into the vacuole or out of the cell into the apoplastic space (Bastías et al., 2010). Physiological mechanisms of tolerance to high levels of $\mathrm{NaCl}$ and $\mathrm{B}$ in amylacea maize have been studied previously, including the salt accumulation capacity of tissues, photosynthetic assimilation, water relations (Bastías et al., 2004b), root hydraulic conductance (Lo), abundance of aquaporins, and ATPase activity (Bastías et al., 2004a; Martínez-Ballesta et al., 2008). Amylacea maize behaves as a salt excluder that overcomes salt stress by the restriction of salt to root tissues, preventing $\mathrm{Na}^{+}$from being transported to leaves and accumulating in photosynthetic tissues. In contrast, B accumulation takes place in leaves and is enhanced under saline conditions. This cultivar did not exhibit symptoms of toxicity to B and salt during a 20-day treatment and was able to maintain relative water content in leaves. Moreover, the presence of B in part mitigated the negative effect of salinity in amylacea (Bastías et al., 2004a, b).

A number of studies have examined the morphological and structural changes induced by salts in higher plants (Hernandez et al., 2001; Yamane et al., 2004). The structural changes caused by salinity occur at several levels of organization. At the whole-plant level, the anatomic-morphological changes that allow plants to tolerate salt effects are mainly directed towards maintaining water use efficiency and balancing the carbon gain (Beerling and Woodward, 1995). Studies on changes in leaf ultrastructure produced by salinity have mainly focused on ultrastructural changes in chloroplasts. Observed changes in rice and tomato leaves include swelling of the thylakoid membrane, accumulating starch grain, distorting of grana stacking and increasing in size and number of plastoglobuli (Sam et al., 2003/2004; Navarro et al., 2007). Changes in the cytoplasm were related to changes in the organelles, invaginations of the plasma membrane (Dekov et al., 2000) and swelling of mitochondrial cristae (Sam et al., 2003/2004). The effects of excess B on foliar structure have also been studied in citrus (Mandarin) (Papadakis et al., 2004a, b) and kiwi plants (Sotiropoulos et al., 2002). Damage to chloroplast morphology, alteration of the membrane systems, changes in grana stacking and increases of the plastoglobuli due to B excess were observed (Papadakis et al., 2004a, b).

Few studies have focused on the effect of salinity on the anatomical and ultrastructural characteristics of plant organs. We analyzed the cell structure and changes in the tissue organization of young leaves of amylacea resulting from high salt and B levels. Studying the structural properties and anatomical changes under conditions of excess salt and $\mathrm{B}$ can provide new insights on the underlying mechanisms of salt limitation and response to B because the physiological functions of tissues are linked to their structural properties.

\section{Materials and methods}

Growth conditions and experimental design

The maize germplasm native to Northern Chile, Zea mays amylacea ("lluteño" local ecotype), was 
germinated in a mixture of perlite and vermiculite $(1: 1 ; v / v)$. Seedlings were grown in plastic pots $(2 \mathrm{~L})$ with four plants per pot and irrigated every two or three days to maintain soil water at field capacity with Hoagland solution containing $20 \mathrm{mM} \mathrm{NO}_{3}$-N/L (González-Moro et al., 1997) adjusted to $\mathrm{pH}$ 5.5. The placement of maize pots was completely randomized. The plants were grown in a greenhouse with an average day/night temperature of $25 / 18{ }^{\circ} \mathrm{C}$ and a relative humidity of $60 / 70 \%$, respectively. Light intensity was set at $350 \mu \mathrm{mol} \mathrm{m}{ }^{-2} \mathrm{~s}^{-1}$ and supplemented with warm-white lamps (Philips SON-T AGRO 400, Belgium), providing a $14 \mathrm{~h}$ photoperiod. Nutrient solutions were prepared using deionized water, and the $\mathrm{pH}$, osmotic potential and conductivity were monitored weekly. During the first ten days after germination, plants were irrigated with the basic nutrient solution to maintain non-saline growing conditions. Subsequently, when plants showed a fully expanded third leaf, they were exposed to an excess of boron and salt for 20 days. The basic nutrient solution without the addition of extra salt ( $\mathrm{NaCl}-0)$ or boron (B-0) was used as the control solution. This basic nutrient solution was supplemented in a factorial design with $100 \mathrm{mM} \mathrm{NaCl}$ (Low salinity, L) or $430 \mathrm{mM}$ $\mathrm{NaCl}$ (High salinity, $\mathrm{H}$ ) and with an excess of $\mathrm{B}$ supplied as boric acid to obtain $20(334 \mu \mathrm{M})$ and $40(668 \mu \mathrm{M}) \mathrm{mg} \mathrm{B} \mathrm{kg}^{-1}$ in the nutrient solution. Stress levels applied in this study were based on the reported concentrations of soil and irrigation water in different sectors the Lluta Valley. The harvesting of fresh plant material was performed between 10:00 and 11:00 A.M.

\section{Preparation of tissue for anatomical studies}

The third leaf of the maize plants was sampled and immediately cut into $2-3 \mathrm{~mm}^{2}$ pieces and fixed in 5\% glutaraldehyde in $0.05 \mathrm{M}$ sodium cacodylate, $\mathrm{pH} 7.4$ at room temperature for $48 \mathrm{~h}$. Later they were vacuum-infiltrated in the same fixative several times until they sank. The segments were fixed at $4{ }^{\circ} \mathrm{C}$ in sodium cacodylate buffer for $3 \mathrm{~h}$ in total and washed three times (1 h each). Subsequently, samples were post-fixed in $1 \%$ osmium tetroxide in sodium cacodylate buffer for $2 \mathrm{~h}$. The samples were dehydrated in an ascending series of acetone (30-100\%) and propylene oxide. After dehydration, the samples were infiltrated with a series of araldite mixtures with propylene oxide (Durcupam ACM). Finally, tissues were embedded in 100\% Araldite resin. Sections were cut with an ultramicrotome (Ultratome III, LKB Productor, and Control Unit Type 8802A). For light microscopy, thin sections $(1 \mu \mathrm{m})$ were stained with toluidine blue (equal volumes of $1 \%$ basic toluidine blue and $1 \%$ Na tetraborate) and examined with a photo-microscope (Olympus BX 51). Ultrathin sections $(<1 \mu \mathrm{m})$ were stained with uranyl acetate and lead citrate to be observed with a transmission electron microscope (TEM) (Philips 208C, operating at $80 \mathrm{kV}$ ). Microphotographs were taken from at least three sites in three different sections randomly, whose representative pictures are presented. Quantitative anatomical data were calculated using the leaf transverse section diagram according to Dengler et al. (1994).

\section{Enzyme extraction and assays}

Enzyme activities were determined in fully expanded third-position leaves from frozen material stored at $-80{ }^{\circ} \mathrm{C}$. Extractions were performed at $4{ }^{\circ} \mathrm{C}$ from plant tissue $(0.1 \mathrm{~g})$ ground in liquid nitrogen using a pre-chilled mortar and pestle. Plant material was homogenized with $100 \mathrm{mM}$ Tris-HCl buffer ( $\mathrm{pH}$ 7.2) containing 5 mM DTT, 10 $\mathrm{mM} \mathrm{MgCl}_{2}, 1$ mM EDTA* $\mathrm{Na}_{2}, 2 \mathrm{mM} \mathrm{Cl}_{2} \mathrm{Mn}, 10 \%$ glycerol and $2 \%$ insoluble PVPP. The homogenate was centrifuged at $15000 \mathrm{~g}$ for $5 \mathrm{~min}$ at $4{ }^{\circ} \mathrm{C}$, and the resulting supernatant was used to determine phosphoenolpyruvate carboxylase (PEPC, EC 4.1.1.31) and NADP-malic enzyme (NADP-ME, EC 1.1.1.40). The extraction and assay for activity of PEPC was performed according to the method of Jiao and Chollet (1988). The enzymatic reaction for PEPC was measured at $30^{\circ} \mathrm{C}$; the assay mixture contained $100 \mathrm{mM}$ TRIS-HCl buffer 
(pH 7.2) with $2 \mathrm{mM}$ DTT, $5 \mathrm{mM} \mathrm{NaHCO}, 5 \mathrm{mM}$ $\mathrm{KHCO}_{3}, 5$ mM G6P, $2.5 \mathrm{mM}$ PEP, 10000 units of malate dehydrogenase (MDH, EC 1.1.1.37), $0.2 \mathrm{mM} \mathrm{NADH}$ and the appropriate amount of the enzymatic extract in a total volume of 0.3 $\mathrm{mL}$. PEPC activity was measured spectrophotometrically as the decrease in absorbance at 340 $\mathrm{nm}$ due to NADH and expressed as $\mu$ mol NADH oxidized $\mathrm{mg}^{-1}$ protein $\mathrm{h}^{-1}$. Extraction and activity measurement of NADP-malic enzyme was performed according to Kanai and Edwards (1973). The enzymatic reaction was measured at $30^{\circ} \mathrm{C}$; the assay mixture contained $50 \mathrm{mM}$ Tris- $\mathrm{HCl}$ buffer (pH 8.3), 5 mM L-malate, 0.5 mM NADP, $0.1 \mathrm{mM}$ $\mathrm{Na}_{2}$ EDTA and $10 \mathrm{mM} \mathrm{MgCl}{ }_{2}$. The NADP-ME activity was determined spectrophotometrically, monitoring the increase in the absorbance at 340 $\mathrm{nm}$ due to NADPH that was expressed as $\mu \mathrm{mol}$ NADPH produced $\mathrm{mg}^{-1}$ protein $\mathrm{h}^{-1}$.

\section{Gel electrophoresis and protein blot analysis}

Soluble proteins were extracted at $4{ }^{\circ} \mathrm{C}$ from frozen powdered leaves in a buffer containing $50 \mathrm{mM}$ Tris- $\mathrm{HCl} \mathrm{pH}$ 7.5, $1 \mathrm{mM}$ EDTA, $1 \mathrm{mM}$ $\mathrm{MgCl}_{2}, 0.5 \%$ (w/v) PVPP, $0.1 \%$ (v/v), 2-mercaptoethanol, 20\% (v/v) glycerol, $1 \mathrm{mM}$ phenylmethylsulfonylfluoride (PMSF) and $4 \mathrm{mM}$ leupeptin. Protein was separated by SDS polyacrylamide gel electrophoresis (SDS-PAGE) (Laemmli, 1970). For analysis of leaf protein profiles, the percentage of polyacrylamide used in gels was $12 \%$ in the resolving gel and $4 \%$ in the stacking gel. Twenty micrograms of protein were loaded in each lane. After electrophoretic separation (150 $\mathrm{mV}$ for $45 \mathrm{~min}$ ), the gel was stained with Coomassie Blue R-250 to quantify the amount of polypeptides. The apparent molecular weights of the polypeptide bands were estimated using prestained molecular weight markers for SDSPAGE standards (Bio-Rad). The polypeptides were electrophoretically transferred to a nitrocellulose membrane (Amersham Hybond ECL, RPN 203D $0.45 \mu \mathrm{m}$ pore size) overnight at low voltage. After blotting, the membrane was blocked with $5 \%$ powdered non-fat dry milk in TBS containing $0.1 \%$ Tween 20 for $1 \mathrm{~h}$ at room temperature. The immunodetection was probed with anti-NADPME (1:1000) and anti-PEPC (1:1000) for $2 \mathrm{~h}$ at room temperature. Goat anti-rabbit IgG-alkaline phosphatase conjugate (Bio-Rad) at a dilution of 1:10000 was used as the secondary antibody for the detection of proteins. Scanning the density of the different protein bands and calculations was carried out with 1D-Manager (v. 2.0) software.

\section{Statistical analysis}

The experimental data were analyzed by ANOVA and the differences were compared by employing the Duncan test with a significance of $\mathrm{P} \leq 0.05$ using SPSS software, version 11/PC (SPSS 11.0, 2001). All experiments described were repeated three times independently with six replications each time.

\section{Results}

\section{Effect of salinity and B excess on leaf anatomy}

The effects of excess salinity and B on leaf structure was evaluated by light microscopy performed on leaf thin sections of control versus stressed plants. Leaves of Zea mays amylacea exhibited typical Kranz-type anatomy (Figure 1A). Bundle sheath cells (BSC) appeared as large chlorophyllous cells in a single cell layer around the vascular bundles (veins), forming a compact sheath of isodiametric cells in the form of a crown. Mesophyll cells (MC) were radially arranged around the BSC. Under light microscopy, the presence of chloroplasts was easily recognized in the $\mathrm{MC}$ and BSC. The chloroplasts in the BSC showed their characteristic centrifugal position. The upper and lower epidermis were a monostratified layer of cells delimited towards the outside by a thick and smooth cellular wall. The application of excess B under non-saline conditions did not affect the organization of foliar tissue. Thus, as 
observed in the leaf cross-section of plants grown with extra B (20 and $40 \mathrm{mg} \mathrm{kg}^{-1}$ ) (Figure 1B), the Kranz anatomy and the large vascular bundles were clearly maintained and did not differ from the control plants. The application of the low salinity treatment $(100 \mathrm{mM} \mathrm{NaCl})$ for 20 days in the presence or absence of $\mathrm{B}$ did not cause any alterations in the organization of the foliar tissue or in the structure of the small, intermediate or large vascular bundles, as observed in the leaf cross-section (data not shown). Under conditions of high salinity, regardless of the presence or absence of B, slight changes were observed in the upper and lower epidermis (Figure 1C). Only high salinity induced the formation of irregular, dorsiventrally deformed and compressed cell walls in epidermis cells. In addition, greater intercellular space and more distorted spaces between cell walls of MC in the leaf tissue were observed (Figure 1C).

Morphometric parameters were estimated for the foliar tissue of amylacea plants under different B and salt treatments (Table 1). Leaf thickness, the distance between the adaxial and abaxial surfaces, decreased significantly with the increase in $\mathrm{NaCl}$ concentration in the nutrient solution. Under non-saline conditions, the presence of boron significantly increased leaf thickness, up to $40 \%$. Similarly, under saline conditions, mainly under high salinity, a significant recovery of leaf thickness was observed when extra B was applied, with an increase of more than $30 \%$. The diameters of the vascular bundles and the distance and the number of MCs between two adjacent vascular bundles did not show statistically significant variation between the different treatments. The number of MCs adjacent to vascular bundles showed a statistically significant decrease under high salinity independent of B. As a result, an average of approximately $14 \mathrm{MCs}$ were arranged around the vascular bundle in the control and low salinity-treated leaves, whereas an average of $10 \mathrm{MC}$ occurred around the vascular bundles in leaves of plants treated with the high salinity solution $(430 \mathrm{mM})$. However, no changes were observed in the diameter of the vascular bundle sheath or in the distance between two proximate vascular bundles. The mesophyll was formed by a one-cell layer between the upper epidermis and lower epidermis in the space between two vascular bundles. The number of MC lodged between two vascular bundles was also maintained at 4-5. Chloroplast number in BSC was substantially reduced (45\%) under saline treatments although no significant difference in chloroplast number in MC between treatments was found (Table 1).

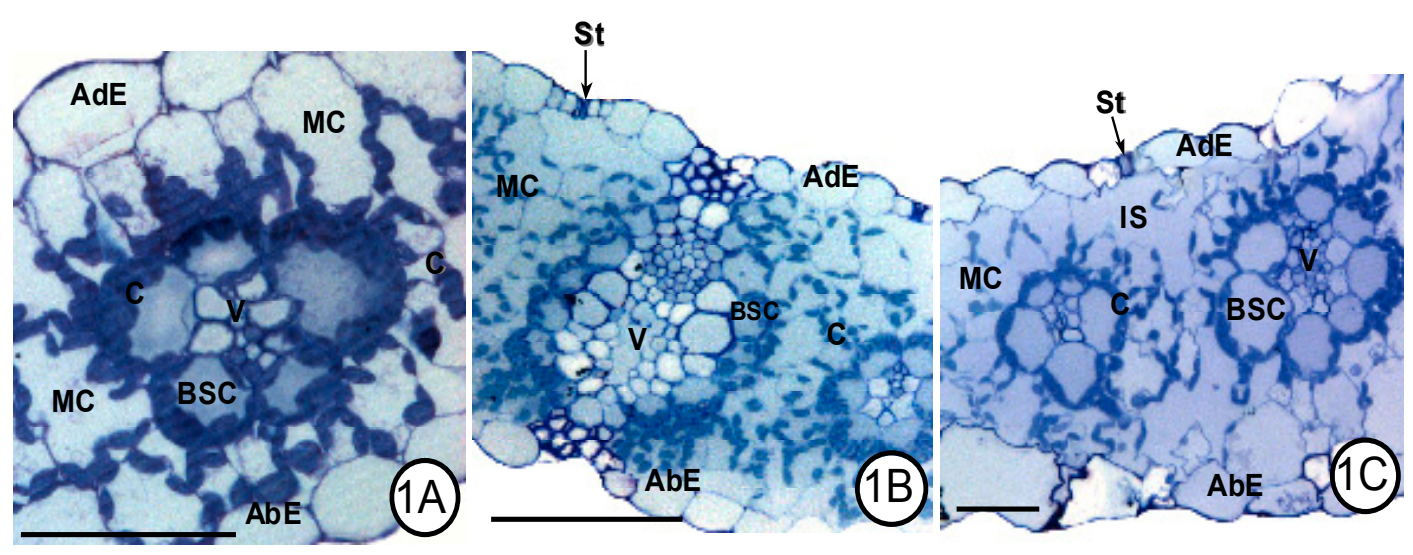

Figure 1. Light micrographs of cross sections of leaves in control plants (1A), $20 \mathrm{mg} \mathrm{B} \mathrm{kg}^{-1}$ (1B) and $430 \mathrm{mM} \mathrm{NaCl}$ (1C) of Zea mays L. amylacea. A-C: general view, leaf cell organization with typical Kranz anatomy. Bars represent $50 \mu \mathrm{m}$. Labels: AbE, abaxial epidermis cell; AdE, adaxial epidermis cell; BSC, bundle sheath cell; C, chloroplasts; MC, mesophyll cell; V, vascular bundle; St, stomata; IS, intercellular space. 
Table 1. Salt and boron effect on leaf morphological and anatomic parameters of maize plants (Zea mays L. amylacea). Treatments: $0 \mathrm{mM} \mathrm{NaCl}$ (control), $100 \mathrm{mM} \mathrm{NaCl}, 430 \mathrm{mM} \mathrm{NaCl}, 0$ ppm B (B0), 20 ppm B (B20) and 40 ppm B (B40). Values represent the mean $\pm \mathrm{SE}(\mathrm{n}=10)$. Values with the same letter are not significantly different according to LSD at a level $\mathrm{P} \leq 0.05 .20 \mathrm{mg}$ of protein was loaded in each track. Values are means of three plants.

\begin{tabular}{|c|c|c|c|c|c|c|c|}
\hline Treatments & & $\begin{array}{l}\text { Leaf thickness } \\
(\mathrm{mm})\end{array}$ & $\begin{array}{l}\text { BSC diameter } \\
(\mathrm{mm})\end{array}$ & $\begin{array}{l}\text { BSC separation } \\
(\mathrm{mm})\end{array}$ & $\begin{array}{l}\text { MC adjacent to } \\
\text { vascular bundles }\end{array}$ & $\begin{array}{c}\text { BSC chloroplast } \\
\text { number }\end{array}$ & $\begin{array}{c}\text { MC chloroplast } \\
\text { number }\end{array}$ \\
\hline \multirow{3}{*}{$\begin{array}{l}\mathrm{NaCl} \\
(0 \mathrm{mM})\end{array}$} & B0 & $300.00 \pm$ & $134.28 \pm 16.10 \mathrm{a}$ & $251.43 \pm 21.05 \mathrm{a}$ & $15.50 \pm 1.23 \mathrm{~b}$ & $6.27 \pm 0.29 b$ & $4.97 \pm 0.32 \mathrm{ab}$ \\
\hline & $\mathrm{B} 20$ & $508.56 \pm 13.28 \mathrm{a}$ & $142.85 \pm 6.40 \mathrm{a}$ & $252.85 \pm 14.20 \mathrm{a}$ & $12.00 \pm 0.89 \mathrm{~d}$ & $7.55 \pm 0.07 \mathrm{ab}$ & $4.80 \pm 0.42 \mathrm{ab}$ \\
\hline & B40 & $342.84 \pm 11.28 b$ & $132.85 \pm 3.70 \mathrm{a}$ & $224.43 \pm 6.13 \mathrm{a}$ & $16.00 \pm 1.30 \mathrm{a}$ & $8.51 \pm 0.47 \mathrm{a}$ & $5.66 \pm 0.44 \mathrm{a}$ \\
\hline \multirow{3}{*}{$\begin{array}{l}\mathrm{NaCl} \\
(100 \mathrm{mM})\end{array}$} & B0 & $274.67 \pm 6.49 \mathrm{~d}$ & $157.14 \pm 6.40 \mathrm{a}$ & $210.00 \pm 21.80 \mathrm{a}$ & $15.00 \pm 0.78 b$ & $6.20 \pm 0.54 \mathrm{~b}$ & $5.40 \pm 0.57 \mathrm{a}$ \\
\hline & $\mathrm{B} 20$ & $314.59 \pm 16.67 \mathrm{bc}$ & $131.42 \pm 11.93 \mathrm{a}$ & $250.00 \pm 6.40 a$ & $12.00 \pm 0.83 \mathrm{~d}$ & $6.23 \pm 0.46 \mathrm{~b}$ & $4.10 \pm 0.20 \mathrm{ab}$ \\
\hline & B40 & $320.56 \pm 13.98 b c$ & $142.85 \pm 9.06 \mathrm{a}$ & $231.43 \pm 7.14 \mathrm{a}$ & $14.00 \pm 0.92 \mathrm{c}$ & $4.85 \pm 0.54 \mathrm{c}$ & $4.30 \pm 0.41 \mathrm{ab}$ \\
\hline \multirow{3}{*}{$\begin{array}{l}\mathrm{NaCl} \\
(430 \mathrm{mM})\end{array}$} & B0 & $218.99 \pm 2.63 \mathrm{e}$ & $157.14 \pm 18.85 \mathrm{a}$ & $235.71 \pm 3.70 \mathrm{a}$ & $10.00 \pm 0.91 \mathrm{e}$ & $3.50 \pm 0.28 \mathrm{c}$ & $4.80 \pm 0.59 \mathrm{ab}$ \\
\hline & $\mathrm{B} 20$ & $292.46 \pm 23.99 \mathrm{~cd}$ & $167.14 \pm 8.06 \mathrm{a}$ & $247.14 \pm 3.37 \mathrm{a}$ & $11.00 \pm 0.97 \mathrm{e}$ & $3.62 \pm 0.27 \mathrm{c}$ & $3.40 \pm 0.23 \mathrm{~b}$ \\
\hline & B40 & $287.50 \pm 4.66 \mathrm{~cd}$ & $171.43 \pm 16.94 \mathrm{a}$ & $242.85 \pm 5.26 \mathrm{a}$ & $10.00 \pm 0.85 \mathrm{e}$ & $4.50 \pm 0.43 \mathrm{c}$ & $4.00 \pm 0.31 \mathrm{ab}$ \\
\hline
\end{tabular}

\section{Effect of excess salinity and B on leafultrastructure}

The presence of large IS between MC was characteristic in the leaf tissue (Figure 2A). Amylacea maize showed a thin primary cell wall in photosynthetic MC and some other cell types. Between the primary walls of two adjacent $\mathrm{MC}$, the middle lamella held adjoining cells together because of the presence of pectin substances between them. When the three adjacent cells were joined, the cellular maize was visible. This cellular maize is normally formed by pectin-enriched polysaccharides. As cells age, the pectin material in the cellular maize is degraded, thus leading to the appearance of large intercellular spaces.

Mesophyll cells in general showed a lower number of chloroplasts per cell (Figure 1A; Table 1) and smaller chloroplasts (Figures 2A) compared to BSC. MC chloroplasts contained abundant grana thylakoids, a character indicative of the presence of PSII in this cell type to provide reducing power, and showed absence of starch grains (Figure 2A). The BSC chloroplasts were larger and more abundant than $\mathrm{MC}$ chloroplasts and were arranged in an ordered way in a centrifugal position within $\mathrm{BSC}$, according to the typical disposition shown by NADP-ME subtype $\mathrm{C}_{4}$ species, such as maize (Figure 1). The leaf ultrastructure of control plants is shown in Figure 2. In amylacea, the BSC chloroplasts accumulated large starch grains (S) and contained few or no grana (Figure 2B). In addition, the BSC showed the typical large central vacuole (Figure 2A).

The application of the low salinity (100 mM $\mathrm{NaCl}$ ) (Figure 2B) solution did not result in ultrastructural changes in MC or BSC. Alteration in the conformation of the cell wall was not observed; the structure of the primary wall and middle lamella was maintained, similar to what was observed in control leaf cells (Figure 2A).

The most remarkable changes were observed in $\mathrm{MC}$ under high salinity conditions either in presence or absence of B (Figures 2C-2D). First, the leaf cells of amylacea maize in high salinity conditions showed a tendency to increase the thickness of the cell wall and an altered shape and disposition of the plasma membrane (Figure 2C). The MC plasmalemma in salt-stressed plants was partly detached from the cell wall at various positions, indicating plasmolysis, which was not observed in the control plants (Figure 2A). This change led to the formation of small vesicles in the 

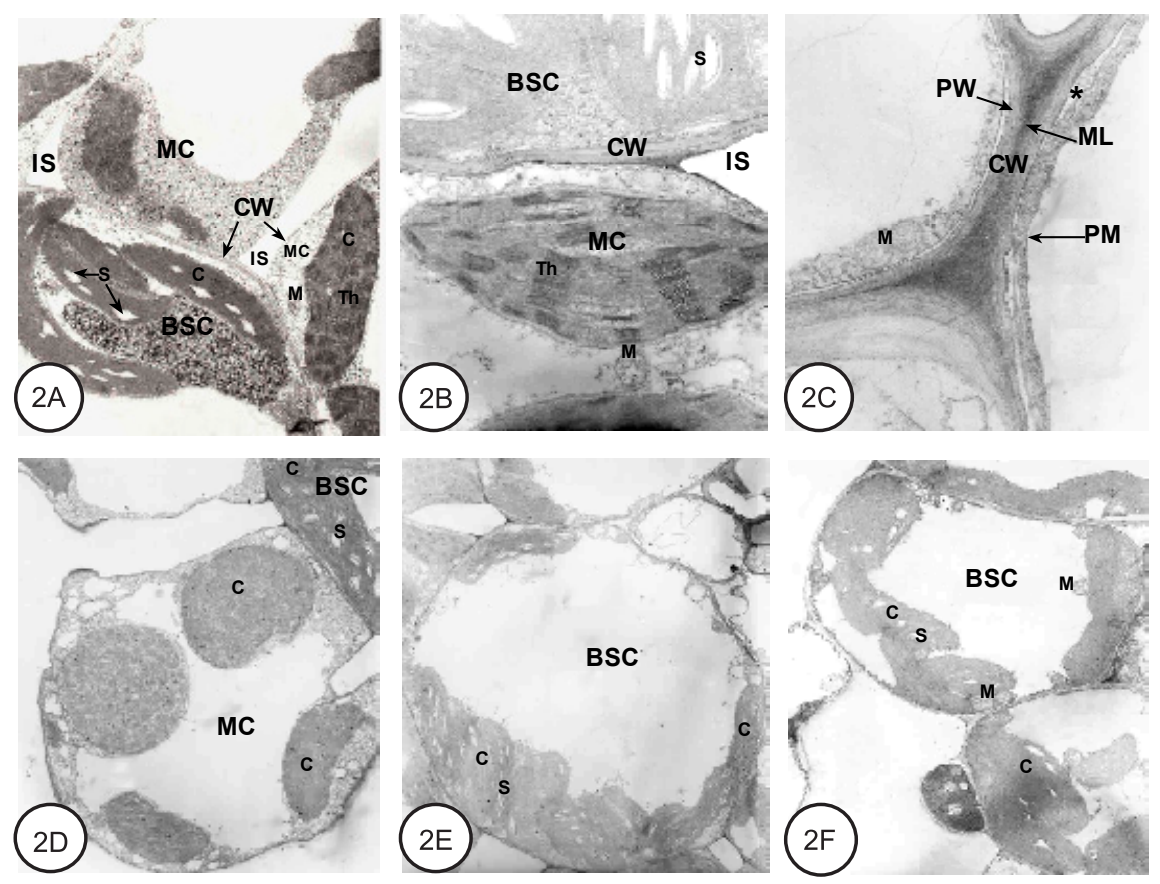

Figure 2. Transmission electron micrographs of leaves in control plant of Zea mays L. amylacea, mesophyll and bundle sheath cell (x 2,000) (2A), chloroplast of mesophyll and bundle sheath cell of salt-treated plant $(100 \mathrm{mM} \mathrm{NaCl}, \mathrm{x} 10,000)(2 \mathrm{~B})$, plasma membrane and cell wall of salt-treated plant $(430 \mathrm{mM} \mathrm{NaCl}, \mathrm{x} 16,000)(2 \mathrm{C})$, chloroplast of mesophyll cell of salt-treated plant $(430 \mathrm{mM} \mathrm{NaCl} \times 2,500)(2 \mathrm{D})$, chloroplast of bundle sheath cell of salt-treated plant $(430 \mathrm{mM} \mathrm{NaCl} \times 2,500)(2 \mathrm{E})$, chloroplast of bundle sheath cell of salt-treated plant (430 $\mathrm{mM} \mathrm{NaCl}+\mathrm{B} 40 \times 3,200)(2 \mathrm{~F})$. Labels: BSC, bundle sheath Cell; C, chloroplasts; CW, cell wall; MC, mesophyll cell; ML, middle lamella; M, mitochondria; PM, plasma membrane; PW, primary cellular wall; IS, intercellular space; Th, thylakoid; S, starch.

space between the cell wall and the plasmalemma (indicated by an asterisk). The marked alteration of plasma membrane integrity was observed as a wavy and diffuse aspect in MCs. Second, some alterations were observed in MC chloroplasts; certain chloroplasts appeared swollen, with a rounded and voluminous aspect (Figure 2D). In addition, a disorganization of the internal system of thylakoid membranes was evident in the distortion of grana stacking and the swelling of stroma in some chloroplasts. However, other chloroplasts showed no alterations in the internal membrane system and thus were similar to the control. The BSC chloroplasts also showed certain disorganization, losing their perpendicular disposition to the cell wall and becoming oriented parallel to the cell wall (Figure 2E); however, other chloro- plasts maintained their normal spatial disposition perpendicular to the cell wall. Additionally, an irregular pattern was observed for the presence of starch grains; some BSC chloroplasts showed few starch grains, while others maintained a normal abundance. Additionally, in BSC chloroplasts a certain dilation of the internal system of thylakoidal membranes was evident, where the separation of stromatic lamellae occurred (Figure 2F). Apart from these changes, structural damage in mitochondria was not observed in either MC or BSC, although swelling took place to some extent (Figure 2F). Plastoglobuli were not observed in amylacea maize, at least in the $3^{\text {rd }}$ fully expanded leaf, under control, saline or B treatments (Figure 2). 
Enzyme activities

The activities of the two enzymes involved in carboxylation and decarboxylation in the $\mathrm{C} 4$ cycle, PEPC and NADP-ME, were affected little by salinity levels or presumed toxic B levels (Figure 3), and their activities remained relatively constant. The activity of PEPC (Figure 3a) was very similar among the different treatments, with values between 40-50 $\mu$ mol NADH mg ${ }^{-1}$ prot $\mathrm{h}^{-1}$ and a slight tendency to increase with salinity. The activity of NADP-ME also increased from $55 \mu \mathrm{mol} \mathrm{NADPH} \mathrm{mg}{ }^{-1}$ prot $\mathrm{h}^{-1}$ in the control to $67.01 \mu$ mol NADPH $\mathrm{mg}^{-1}$ prot $\mathrm{h}^{-1}$ under low salt conditions but decreased with higher salt (Figure $3 b)$. The immunoblotting of PEPC and NADP-ME revealed a major protein with a molecular weight of $90 \mathrm{kDa}$, which corresponded to PEPC and a band whose molecular mass was $48.5 \mathrm{KDa}$, corresponding to NADP-ME (Figure 4).

\section{Discussion}

\section{Boron effect}

The application of excess B in non-saline conditions did not cause visual symptoms or alteration of the anatomy of foliar tissue of amylacea maize. Amylacea did not present any symptoms of toxicity in the presence of $\mathrm{B}$, which makes sense because B behaved as a mobile element inside the plant, and its accumulation in the roots was very low ( $<200$ ppm B). The typical Kranz anatomy of maize was observed under normal and extra B levels. Moreover, there was a tendency towards better photosynthetic performance as indicated by the $\mathrm{CO}_{2}$ assimilation and stomatal conductance (Bastías et al., 2004b) when B was present, which may be explained by an increase in the photosynthetic capacity of mesophyll tissue as the number of MCs surrounding each vascular
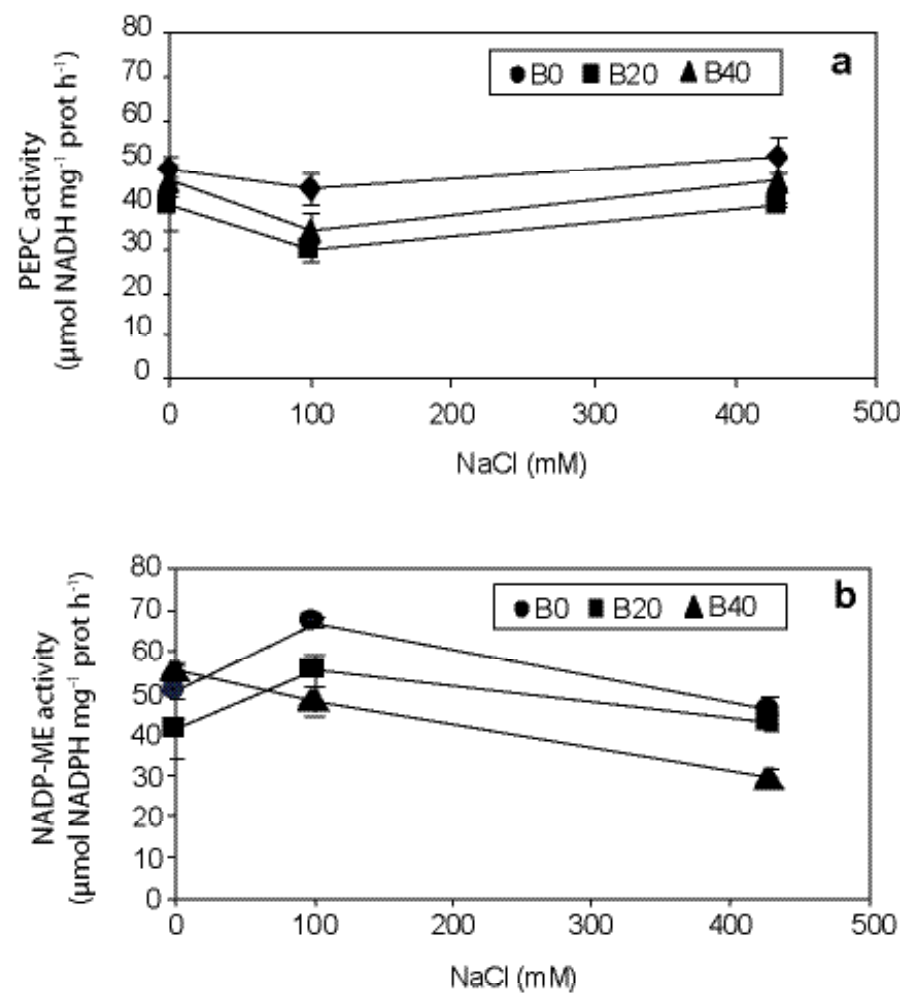

Figure 3. Effect of salinity and excess of B on PEPC activity (a) and NADP-ME activity (b) in leaf extracts of Zea mays L. amylacea after 20 days of treatment with $\mathrm{NaCl}(0 \mathrm{mM} ; 100 \mathrm{mM} ; 430 \mathrm{mM})$ and B (B0, control; $\mathrm{B} 20,20 \mathrm{mg} \mathrm{kg}^{-1}$; B40, $\left.40 \mathrm{mg} \mathrm{kg}^{-1}\right)$. Values represent the mean $\pm \mathrm{SE}$ of three independent experiments. 
a. Western NADP. ME

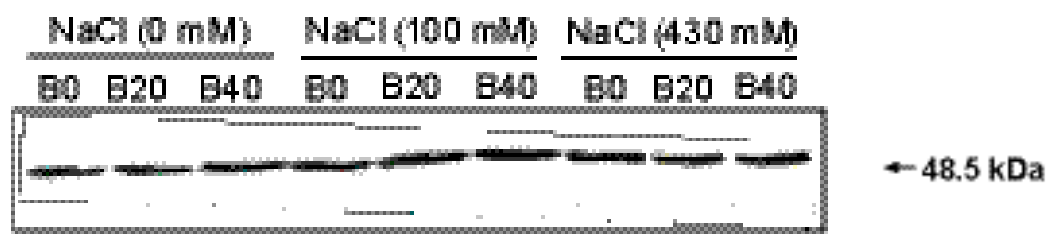

b. Western PEPCase

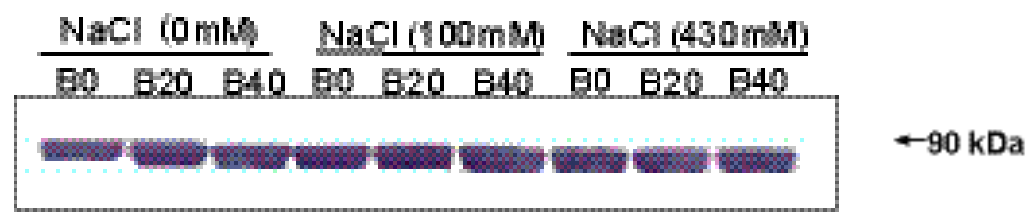

Figure 4. Effect of salinity and excess of B on NADP-ME (a) and PEPC (b) polypeptides in leaves of Zea mays L. amylacea using Western blot analysis after 20 days of treatment with $\mathrm{NaCl}$ and $\mathrm{B}$. (a) the band of $48.5 \mathrm{kDa}$ corresponds to NADP-ME protein and (b) the band of $90 \mathrm{kDa}$ corresponds to PEPC. The relative amount of NADP-ME and PEPC were calculated following densitometry scanning of the Western blot using the value measured for the amount of NADP-ME and PEPC protein present in the plant control as a maximum

bundle as well as the number of chloroplasts in $\mathrm{MC}$ and BSC (increased slightly) (Table 1).

An ameliorative effect of $\mathrm{B}$ on some leaf biomass parameters has also been observed in tobacco plants (Ruiz et al., 2001). Nevertheless, in peach, kiwi, tangerine (Clementina) and orange (Navelina) plants, a reduction in the thickness of the crosssections of the leaf was observed due to the reduction in the thickness of the spongy parenchyma, whose cells showed a disarranged and shrunken appearance, and to the damage in palisade parenchyma and disorganization of mesophyll cells, accompanied by large conspicuous intercellular spaces (Sotiropoulos et al., 2002; Papadakis et al., 2004a, b). The transmission electron microscopy images of amylacea did not reveal remarkable changes in cell structure (Figure 2F). In contrast, considerable effects were reported at the level of the machinery involved in photosynthesis in orange plants (Navelina) and mandarin plants (Clementina) in conditions of excess B. At lower B concentrations, 8 to 16 times less than applied in our study, excess B resulted in a significant decrease in the width, length and relative volume of the chloroplasts of mesophyll cells (Papadakis et al., 2004a, b). At the ultrastructural level, the chloroplast membrane system in the amylacea ecotype did not show any alteration of its aspect or organization (data not shown) in contrast to the results reported in orange and mandarin plants. In these citrus species, B excess did cause a dilation of the thylakoidal membrane system, decrease in thylakoid volume and, in some cases, their partial destruction (Papadakis et al., 2004a, b). The linking of B to some molecules of the cell wall (Bonilla et al., 2010) would reduce the movement of B into the cell, avoiding toxic B accumulation in the protoplasm and organelles. Thus, the beneficial effect of B on leaf area (Bastías et al., 2004b) was manifested in a way in cell structural components because the leaf cross-section area increased (Table 1). The absence of changes in leaf ultrastructure confirmed that cellular structure was well maintained in amylacea maize cells under excess B, at least up to 40 ppm B.

\section{Salt effects}

Amylacea maize behaves as a salt excluder, overcoming salt stress by the restriction of salt 
to root tissues and preventing $\mathrm{Na}^{+}$from being transported to leaves and accumulating in photosynthetic tissues (Bastías et al., 2004a, b). According to previous results (Bastías et al., 2004b), this cultivar was able to accumulate $\mathrm{Na}^{+}$ in root tissues up to $4.5 \%$, while in leaves, this value was 4 times lower, which led a reduction in dry weight between $25-31 \%$ and $33-53 \%$ for roots and leaves, respectively.

In contrast to salt localization, B was distributed to a greater extent in leaves, and its transport to aerial parts was enhanced under salt conditions (Bastías et al., 2004b). Thus, the highest B content ( $850 \mathrm{ppm}$ ) was reached in $100 \mathrm{mM} \mathrm{NaCl}+40$ mg B kg-1-treated leaves, while the highest salt level accumulated in leaf tissue occurred when amylacea plants were grown under $430 \mathrm{mM} \mathrm{NaCl}$, either in the absence or presence of $10 \mathrm{ppm} \mathrm{B.}$ Despite the lower $\mathrm{Na}^{+}$accumulation in leaves compared to roots, the growth of the leaves was more affected than that of the roots. In fact, leaf area diminished in the presence of salts (Bastías et al., 2004b), and leaf thickness decreased in plants grown at high salt levels (Table 1). The size of histological components such as bundle sheath, vascular bundle and bundle sheath-inter separation remained practically unchanged, and the number of MC adjacent to vascular bundles was reduced approximately $28 \%$, which we attribute to the decrease in leaf thickness mainly because of the decrease in photosynthetic mesophyll parenchyma. Additionally, the application of boron prevented the decrease in leaf thickness observed under saline conditions (Table 1) and maintained a relatively good organization of Kranz anatomy (Figure 1B) even when salt accumulation reached $1 \%$ in the tissue (Bastías et al., 2004b).

The distribution of salt to mesophyll cells as consequence of being dragged by the transpirational stream would likely restrict damage mainly to epidermis and mesophyll cells, with minor consequences for BSC. At a minimum, this movement is what can be deduced by the enlarged intercellular spaces between in mesophyll and the compressed cell walls in epidermis cells. Many studies have suggested that reduced cell turgor potential and cell wall elasticity could lead to the formation of small cells and intercellular space area in salt-treated plants (Suarez et al., 1998). Changes observed in MC included a more irregular, smaller and less prismatic shape, which confirmed that the leaf thickness reduction under conditions of salinity was due to a reduction in cell size (Figure 1C). The bundle sheath showed tightly packed cells around the vascular sheath. An adaptive role has been suggested for the bundle sheath under water stress because it stores water to buffer transpiration surges (Barhoumi et al., 2007). As suggested for Aeluropus littoralis, a halophytic salt excreter grown at similar salt levels to amylacea in this study, the osmotic stress induced by salinity has no significant effect on the volume or shape of maize BSC. Although drastic overall changes in the foliar anatomy were not observed, salinity reduced the photosynthetic parenchyma tissue involved in primary carbon assimilation, the mesophyll tissue, by approximately $30 \%$ (Table 1) with respect to bundle sheath cell tissue, the tissue involved in photosynthetic carbon reduction. Both the reduction of MC number (Table 1) and $\mathrm{MC}$ size indicated a limitation of cell growth, likely due to the effect of osmotic stress on cell division and expansion (Hsiao et al., 1985). In addition, considering that leaf thickness was reduced (Table 1), the decrease observed in the $\mathrm{CO}_{2}$ assimilation rate (Bastías et al., 2004b) would not be due to a limitation in mesophyll conductance, opposite to what has been described in other species where leaf thickness increased with salinity (Burssens et al., 2000). Even when leaves accumulated high levels of salts in leaf tissues, stomata did not present any damage (Figure 1C) and seemed to be functional in avoiding water loss and maintaining water status (Bastías et al. 2004a,b). Nevertheless, the reduction in mesophyll photosynthetic capacity due to a reduction in the number and size of mesophyll cells will influence the depletion of photosynthetic capacity. The loss of membrane integrity, confirmed by an increase in its permeability in a previous study (Bastías 
et al., 2004b), would be assumed to be located preferentially also in mesophyll cells. This damage manifested in $\mathrm{MC}$ tissue will likely require adjustments in BSC photosynthetic capacity to maintain a balance, as far as possible, between both types of $\mathrm{C} 4$ photosynthetic cells. The size of BSC was maintained as well as the number of BSCs forming the vascular sheath, but the high depletion (50\%) of the number of chloroplasts in BSC (Figure 1C; Table 1) will tend to compensate the decrease in mesophyll parenchyma photosynthetic capacity. This photosynthetic cooperation between cell types was also manifested in the maintenance of the two key enzyme activities involved in carboxylation and decarboxylation of the $\mathrm{C}_{4}$ cycle when expressed on a protein basis, that is, PEPC located in MC and NADP-ME restricted to BSC, respectively (Figures 3 and 4).

The ultrastructural analysis of amylacea maize leaf by TEM showed alterations only under high salinity levels ( $430 \mathrm{mM} \mathrm{NaCl})$, either in the absence or presence of B (Figure 2C, 2D and 2E). Changes were observed at the level of the cell wall, plasma membrane and chloroplast structure in both BSC and $\mathrm{MC}$, and in some cases, changes in chloroplast disposition and organization of thylakoidal membranes occurred. As an example, according to Lal and Edwards (1996), under water stress conditions, maize presented disorganization of the Kranz anatomy, collapse of mesophyll cells, change in the centrifugal position of the chloroplasts of the BSC towards a centripetal position, collapse of the bulliform cells and loss of intercellular spaces.

Biochemical or ultrastructural modifications/ alterations, produced as a consequence of the different polysaccharide composition of the matrix and the synthesis of cell wall proteins, were also observed previously under saline conditions in some species (Yang and Yen, 2002). A thicker cell wall could help to preserve the pressure potential of the cell in an osmotic medium (Singh et al., 1989). According to previous data recorded for amylacea, plants exposed to high salt levels showed a rigidification of the cell wall because the modulus of elasticity increased under saline conditions of $430 \mathrm{mM} \mathrm{NaCl}$, but the increase was reversed by the addition of extra B (Bastías et al., 2004b). Many studies also suggested that reduced cell turgor potential and cell wall elasticity lead to the formation of small cells and intercellular spaces in salt-treated plants (Suarez et al., 1998).

The invaginations of the plasma membrane have been described in response to saline and water stress (Serraj et al., 1995; Niu et al., 1996). In amylacea maize, the plasma membrane presented small cristae-like invaginations and was detached from the cell wall in several regions (Figure 2C), indicating an incipient plasmolysis that may be caused by excess ions or osmotic stress. This alteration of the plasma membrane is in accordance with the increase in membrane permeability observed in this maize under high salinity conditions of $430 \mathrm{mM} \mathrm{NaCl}$ (Bastías et al., 2004b). Nevertheless, the structural damages observed by TEM in amylacea maize were less than those described in other maize and rice plants under saline conditions (Pareek et al., 1997). Recent evidence has demonstrated that the presence of apparent invaginations in the plasma membrane originated as a result of endosomal vesicles called plasmalemosomas. This presence of located multivesicular bodies could correspond to a situation of relocalization of tonoplast aquaporins because they exhibit PIP-type aquaporin that would help the cell to maintain an osmotic balance between the cytoplasm and the vacuole under stress conditions. Alternatively, multivesicular bodies could mediate the specific solute uptake toward the vacuole to avoid direct contact between ions and cytoplasmic components (Kirch et al., 2000; Vera-Estrella et al., 2004).

Salt stress can affect the ultrastructure of chloroplasts and destroy their membrane systems (Flowers and Yeo, 1995). Several studies have also reported alterations in chloroplast ultrastructure in halophytes and glycophytes affected by salinity (Salama et al., 1994). The effects 
of salt stress were reported to cause swelling of thylakoids, distortion of stroma lamella and grana lamella in chloroplasts and even the dissolution of the chloroplast envelope (Mitsuya et al., 2000; Yamane et al., 2004; Sam et al., 2003/2004). The present study showed that the thylakoids in amylacea under high salinity were able to maintain their integrity. However, the alteration in chloroplast shape did not lead to severe damage of their internal organization or a drastic distortion of the thylakoidal membrane system (Figures 2D, and 2E). Some mesophyll chloroplasts did have a swollen aspect (Figure 2D), likely due to an osmotic imbalance between stroma and cytoplasm as a consequence of salt accumulation (Rahman et al., 2000). These alterations in shape or organization are likely due to the increase in the ionic composition of the stroma matrix. A distortion of grana stacking and stroma swelling were more notable in $\mathrm{MC}$ chloroplasts than in BSC, which was logically expected to happen given the greater damage in mesophyll cells. Chloroplast membrane permeability to $\mathrm{NaCl}$ has been described as low because this ion is excluded from chloroplasts when its level is low in order to maintain relatively constant ionic concentration, but chloroplasts can accumulate $\mathrm{Na}^{+}$when $\mathrm{Na}^{+}$levels are high. The response of $\mathrm{Na}^{+}$exclusion in chloroplasts appears to be an important prerequisite for maintaining photosynthetic capacity under severe salinity conditions and for developing an optimal degree of tolerance to this stress (Flowers and Yeo, 1995). Therefore, the loss of grana stacking in some MC chloroplasts could be related to the increase in the $\mathrm{Na}^{+}$concentration in chloroplast stroma (Utrillas and Alegre, 1997), and this osmotic imbalance between stroma and cytoplasm will cause that chloroplasts take this globular, spherical aspect (Figure 2D). The maintenance of the organization of thylakoidal structure under high salinity would explain a relatively high photosynthetic capacity of this maize (Bastias et al., 2004a, b). The photosynthetic assimilation rate showed a decrease of only $22 \%$, apparently with no structural damage to the photochemical apparatus or its functioning, as reflected by the maintenance of fluorescence parameters (Bastías et al., 2004b). Starch grains are typically restricted to BSC chloroplasts in $\mathrm{C}_{4}$ plants (Leegood, 1985). It has been reported that starch accumulation is a generalized effect in salt-stressed plants (Barhoumi et al., 2007). In amylacea maize plants under high salt conditions, some BSC showed a starch grain accumulation (Figures 2D and 2E). An increase in starch grains in chloroplasts under saline conditions may be attributed to either damage to the sucrose-phosphate synthase present in the cytosol, directing the triose phosphate pathway towards starch synthesis, or to a toxic effect of salts on the enzymes involved in starch degradation (Rahman et al., 2000). It is important to note the total absence of plastoglobuli in chloroplasts in control and salt-boron-treated plants of amylacea maize (Figure 2), these lipid droplets were found in the cytoplasm of other plants treated with salt or exposed to water stress and may be a result of loose lipids in the cell membrane (Rahman et al., 2000). This characteristic indicates that salt-boron tolerance in amylacea maize could be partly explained by the absence of plastoglobuli in chloroplasts maintaining membrane integrity, potentially indicating a greater resistance to oxidative damage. The activities of $\mathrm{C}_{4}$ photosynthetic enzymes resulted in a slight increase in PEPCase activities and a decrease in NADPME activities due to salinity (Figure 3), whereas almost no visible damage in the structure of $\mathrm{MC}$ and BSC chloroplasts (Figure 2) as has been previously reported by Omoto et al. (2012) in maize cv Honey Bantam as adaptation responses to salinity. The immunoblotting of PEPC and NADP-ME revealed no drastic changes in its expression, confirming the degree of tolerance of both stresses of amylacea (Figure 4).

In conclusion, the plants did not exhibit severe symptoms of toxicity to either $\mathrm{NaCl}$ or boron. This study shows that in amylacea maize, the MC and BSC in leaves had different responses to salinity, but there was very little change in the anatomi- 
cal parameters and cell ultrastructure, including the absolute absence the plastoglobuli. The anatomical characteristics of the leaf confirmed the positive effect of B on the growth of amylacea under saline conditions. These properties may be responsible for their ability to withstand this stressful environment.

\section{Acknowledgements}

This study was funded partly by Project UTAMayor 9720-13 and Proyecto FIC P88 Código BIP 30110585-0 (Arica-Chile).

\title{
Resumen
}

\begin{abstract}
E.I. Bastías, M.B. González-Moro y C. González-Murua. 2013. Efectos interactivos del exceso de boro y salinidad en la histología y ultraestructura de hojas de Zea mays amylacea del valle de Lluta (Arica-Chile). Cien. Inv. Agr. 40(3): 581-595. El maíz se cultiva en todo el mundo, se produce un mayor peso del maíz cada año, más que cualquier otro grano. Las respuestas de maíz a la salinidad se han centrado en aspectos fisiológicos, pero pocos estudios se han enfocado a los efectos de la salinidad sobre las características anatómicas y ultraestructurales de los diferentes órganos de la planta. Se analizó la estructura de la célula y la alteración en la organización del tejido en las hojas jóvenes de Zea mays L. amylacea como consecuencia de la alta concentración de los niveles de salinidad y boro (B). Las concentraciones fueron de $100 \mathrm{mM}$ de $\mathrm{NaCl}$ (baja salinidad, L) o $430 \mathrm{mM}$ de $\mathrm{NaCl}$ (de alta salinidad, H) en el caso de los tratamientos de solución salina, o con un exceso de B suministrado como ácido bórico para obtener $20(334 \mu \mathrm{M})$ y $40(668 \mu \mathrm{M}) \mathrm{B} \mathrm{mg} \mathrm{kg}^{-1}$ en la solución de nutritiva durante 20 días. La aplicación de $\mathrm{B}$ en condiciones no salinas y de baja salinidad no provocaron en cambios ultraestructurales en las células del mesófilo (CM) o células de la vaina del haz $(\mathrm{CVH})$. En condiciones de alta salinidad las células de las hojas de amylacea mostraron algunas alteraciones en los cloroplastos de CM, mostrando un aspecto hinchado y redondeado. Los cloroplastos de CVH pierden su disposición perpendicular a la pared celular. Por otra parte, la ausencia absoluta plastoglobulina en las células, podría indicar una mayor resistencia al daño oxidativo.
\end{abstract}

Palabras clave: Amylacea, maíz amiláceo, anatomía de la planta, histología, salinidad.

\section{References}

Barhoumi, Z., W. Djebali, W. Chaıbi, C.H. Abdelly, and A. Amaoui. 2007. Salt impact on photosynthesis and leaf ultrastructure of Aeluropus littoralis. Journal of Plant Research 120:529-537.

Bastías, E., N. Fernandez-Garcia, and M. Carvajal. 2004a. Aquaporin functionality in roots of Zea mays in relation to the interactive effects of boron and salinity. Plant Biology 6:415-421.

Bastías, E., M.B. González-Moro, and C. GonzálezMurua. 2004b. Zea mays L. amylacea from the Lluta Valley (Arica-Chile) tolerates salinity stress when high levels of boron are available. Plant and Soil 267: 73-84.

Bastías, E., C. Alcaraz-López, I. Bonilla, M.C. Martínez-Ballesta, L. Bolaños, and M. Carvajal. 2010. Interactions between salinity and boron toxicity in tomato plants involve apoplastic calcium. Journal of Plant Physiology 167: 54-60.

Beerling, D.J., and F.I. Woodward. 1995. Stomatal responses of variegated leaves to $\mathrm{CO}_{2}$ enrichment. Annals Botany 75:507-511.

Bonilla, I., J. Abadía, and L. Bolaños. 2010. Introduction to mineral nutrition of plants. In: A. González-Fontes, A. Gárate and I. Bonilla (eds.). 
Agricultural Sciences: Topics in Modern Agriculture. Studium Press, Houston, USA. p. 145-171.

Burssens, S., K. Himanen, B. Van de Cotte, T. Beeckman, M. Van Montagu, D. Inze, and N. Verbruggen. 2000. Expression of cell cycle regulatory genes and morphology alterations in response to salt stress in Arabidopsis thaliana. Planta 211:632-640.

Cramer, G.R., G.J. Alberico, and C. Schmidt. 1994. Salt tolerance is not associated with the sodium accumulation of two maize hybrids. Australian Journal Plant Physiology 21:675-692.

Dekov, I., T. Tsonev, and I.Yordanov. 2000. Effects of water stress and high-temperature stress on the structure and activity of photosynthethic apparatus of Zea mays and Helianthus annus. Photosynthetica 38:361-366.

Dengler, N., R. Dengler, P. Donnelly, and P. Hattersley. 1994. Quantitative leaf Anatomy of $\mathrm{C}_{3}$ and $\mathrm{C}_{4}$ grasses (Poaceae): bundle sheath and mesophyll surface area relationships. Annals of Botany $73: 241-255$.

Flowers, T.J., and A.R. Yeo. 1995. Breeding for salinity resistance in crop plants. Where next?. Australian Journal of Plant Physiology 22:875-884.

González-Moro, B., M. Lacuesta, J.M. Becerril, C. González-Murua, and A. Muñoz-Rueda. 1997. Glycolate accumulation causes a decrease of photosynthesis by inhibiting RUBISCO activity in maize. Journal of Plant Physiology 150:388-394.

Hernández, J.A., M.A. Ferrer, A. Jiménez, A. RosBarceló, and F. Sevilla. 2001. Antioxidant systems and $\mathrm{O}_{2}-\mathrm{H}_{2} \mathrm{O}_{2}$ production in the apoplast of Pisum sativum L. leaves: its relation with $\mathrm{NaCl}-$ induced necrotic lesions in minor veins. Plant Physiology 127:817-834.

Hsiao, T.C., W.K. Silk, and J. Jing. 1985. Leaf growth and water deficits: biophysical effects. Cambridge Univ. Press. p. 239-266.

Jiao, J., and R. Chollet. 1988. Light/dark regulation on maize leaf phosphoenolpyruvate carboxylase by in vivo phosphorilation. Arch Biochemical and Biophysical 261: 409-417.

Kanai, R. and G.E. Edwards. 1973. Separation of mesophyll protoplasts and bundle sheath cells from maize leaves for photosynthetic studies. Plan Physiology 51: 1133-1137.

Kirch, H.H., R. Vera-Estrella, D. Golldack, F. Quigley, C.B. Michalowski, B.J. Barkla, and H.J. Bohnert. 2000. Expression of water channel proteins in Mesembryanthemumcrystallinum. Plant Physiology 123: 111-124.

Laemli, U. 1970. Cleavage of structural proteins during the assembly of the head of bacteriophageT4. Nature 227:680-686.

Lal, A., and G.E. Edwards. 1996. Analysis of inhibition of photosynthesis under water stress in the $\mathrm{C}_{4}$ species Amaranthus cruentus and Zea mays: electron transport, $\mathrm{CO}_{2}$ fixation and carboxylation capacity. Australian Journal of Plant Physiology 23:403-412.

Leegood, R.C. 1985. The intercellular compartmentation of metabolites in leaves of Zea mays. Planta $164: 163-171$

Martínez-Ballesta, M.C., Bastías E., C. Zhu, A.R. Schäffner, B. González-Moro, C. GonzálezMurua C, and Carvajal M. 2008. Boric acid and salinity effects on maize roots. Response of aquaporins ZmPIP1 and ZmPIP2, and plasma membrana $\mathrm{H}^{+}$-ATPase, in relation to water and nutrient uptake. Physiology Plantarum 132:479-490.

Mitsuya, S., Y. Takeoka, and H. Miyake. 2000. Effects of sodium chloride on foliar ultrastructure of sweet potato (Ipomoea batatas Lam.) plantlets grown under light and dark conditions in vitro. Journal of Plant Physiology 157:661-667.

Navarro, A., S. Boñan, E. Olmos, and M.J. Sánchez-Blanco. 2007. Effects of sodium chloride on water potential components, hydraulic conductivity, gas exchange and leaf ultrastructure of Arbutus unedo plants. Plant Science 172:473-480.

Niu, X., B. Damsz, A.K. Kononowicz, R.A. Bressan, and P.M. Hasegawa. 1996. NaCl-induced alterations in both cell structure and tissue-specific plasma membrane $\mathrm{H}^{+}$-ATPase gene expression. Plant Physiology 111:679-686.

Novoa, R.S., P. Villaseca, P. Del Canto, J.L. Ravanet, C. Sierra, and A. Del Pozo. 1989. Mapa Agroclimático de Chile. INIA. Santiago, Chile. 221 pp. 
Omoto, E., M. Taniguchi, and H. Miyake. 2012. Adaptation responses in $\mathrm{C} 4$ photosynthesis of maize under salinity. Journal of Plant Physiology 169:469-477.

Papadakis, I.E., K.N. Dimassi, A.M. Bosabadilis, I.N. Therios, A. Patakas, and A. Iannakoula. 2004a. Boron toxicity in "Clementine" mandarin plants grafted on two rootstocks. Plant Science 166:539-547.

Papadakis, I.E., K.N. Dimassi, A.M. Bosabadilis, I.N . Therios, A. Patakas, and A. Innakoula. 2004b. Effects of boron excess on some physiological and anatomical parameters of "Navelina" orange plants grafted on two rootstocks. Environmental and Experimental Botany 51:247-257.

Pareek, A., S.L. Singla, and A. Grover. 1997. Shortterm salinity and high temperature stress-associated ultrastructure alterations in young leaf cells of Oryza sativa L. Annals Botany 80:629-639.

Pessarakli, M. and I. Szabolics. 1999. In: M. Pessarakli (ed.). Handbook of Plant and Crop Stress. $2^{\text {nd }}$ ed'. Marcel Dekker, New York. p. 1-16.

Rahman, M.S., T. Matsumuro, H. Miyake, and Y. Takeoka. 2000. Salinity induced ultrastructural alterations in leaf cells of rice (Oryza sativa L.). Plant Production Science 3:422-429.

Ruiz, J.M., L.R. Lopez-Lefrere, E. Sánchez, R.M. Rivero, P.C. García, and L. Romero. 2001. Preliminary studies on the influence of boron on the foliar biomass and quality of tobacco leaves subjected to NO-3 fertilization. Journal of the Science of Food and Agriculture 81:739-744.

Sam, O., C. Ramírez, M.J. Coronado, P.S. Testillano, and C. Risueño. 2003/2004. Changes in tomato leaves induced by $\mathrm{NaCl}$ stress: leaf organization and cell ultrastructure. Biologia Plantarum 47:361-366.

Serraj, R., P. Fleurat-Lessard, B. Jaillard, and J.J. Drevon. 1995. Structural changes in the innercortex cells of soybean root-nodules are induced by short-term exposure to high salt or oxygen concentrations. Plant, Cell and Environment 18:455-462.

Shi, H.Z., M. Ishitani, C. Kim, and J.K. Zhu. 2000. The Arabidopsis thaliana salt tolerance gene $\mathrm{SOS} 1$ encodes a putative $\mathrm{Na} / \mathrm{H}$ antiporter. Proc. Natl. Acad. Sc. USA 97: 6896-6901.

Singh, N.K., E. Nelson, D. Kuhn, P.M. Hasegawa, and R.A. Bressan. 1989. Molecular cloning of osmotin and regulation of its expression by ABA and adaptation to low water potential. Plant Physiology 90:1096-1101.

Sotiropoulos, T.E., I.N. Therios, K.N. Dimassi, A.M. Bosabalidis, and G. Kofidis. 2002. Nutritional status, growth, $\mathrm{CO}_{2}$ assimilation, and leaf anatomical responses in two kiwifruit species under boron toxicity. Journal of Plant Nutrition 25:1249-1261.

Suarez, N., M.A. Sobrado, and E. Medina. 1998. Salinity effects on the leaf water relations component sand ion accumulation patterns in Avicennia germinans L. seedlings. Oecologia 114:299-304.

Utrillas, M.J., and L. Alegre. 1997. Impact of water stress on leaf anatomy and ultrastructure in Cynodon dactylon (L.) Pers. under natural conditions. International Journal of Plant Sciences 158:313-324.

Vera Estrella, R., B.J. Barkla, H.J. Bohnert, and O. Pantoja. 2004. Novel regulation of plant aquaporins. Plant Physiology 135:2318-2329.

Yamane, K., S.H. Mitsuya, M. Kawasaki, M. Taniguchi, H. and H. Miyake. 2004. Salinity-induced chloroplast damages in rice leaves (Oryza sativa L.) are reduced by pretreatment with methyl viologen. Proceeding 4th International Crop Science Congress, Brisbone, Australia. p. 7. 
